\title{
KEBERLANJUTAN KEMITRAAN PETANI PLASMA TEH DAN PT. PAGILARAN : BAGAIMANA DAN APA YANG MEMENGARUHI?
}

\author{
Hani Perwitasari, Arif Wahyu Widada*, Anung Pranyoto, Jangkung Handoyo Mulyo, \\ Sugiyarto, Herdiana Anggrasari \\ Departemen Sosial Ekonomi Pertanian, Fakultas Pertanian, Universitas Gadjah Mada. \\ Jl. Flora, Bulaksumur, Karang Malang, Caturtunggal, Depok, Sleman, Yogyakarta 55281 \\ *Corresponding author: arif.w.widada@ugm.ac.id
}

\begin{abstract}
Many Nucleus Estate-Small holding (NES) coo-partnerships often experience dynamics and leave several problems for both parties engaged in the partnership, and in serious way, it may threaten the sustainability of the partnership. This research's objectives are 1) to determine the level of willingness to sustain the NES coo-partnership, and 2) to analyze the determinant factors of the willingness to sustain the NES coo-partnership. Location of the research comprises two villages namely Kaliboja and Kaliombo, located in Paninggaran sub-district, Pekalongan regency. Ninety tea farmers selected by using convenience sampling method are involved and interviewed. Descriptive method and ordered logistic regression are employed to answer the objectives of the research. The result shows that most farmers are willing to sustain the NES coo-partnership. Moreover, the determinant factors of the willingness to sustain partnerships are the age of farmer, farmer's tea production, and partnership effectiveness.
\end{abstract}

Keywords: farmer, pagilaran, partnership, tea

\begin{abstract}
Abstrak: Kerjasama kemitraan dengan pola inti-plasma sering kali mengalami dinamika pasang surut dan meninggalkan persoalan bagi kedua belah pihak yang terlibat dalam kerjasama, dan dalam skala yang besar dapat mengancam keberlanjutan kerjasama kemitraan. Penelitian ini bertujuan untuk mengetahui tingkat kesediaan petani plasma teh untuk melanjutkan kerjasama kemitraan dengan perusahaan inti, serta mengetahui faktor-faktor yang memengaruhi kesediaan untuk melanjutkan kerjasama kemitraan. Penelitian ini dilaksanakan di Desa Kaliboja dan Kaliombo, Kecamatan Paninggaran, Kabupaten Pekalongan dengan melibatkan 90 petani plasma teh yang dipilih dengan metode convenience sampling. Analisis deskriptif digunakan untuk mengetahui tingkat kesediaan petani untuk melanjutkan kemitraan, dan regresi ordinal logit digunakan untuk mengetahui faktor-faktor yang berpengaruh pada kesediaan melanjutkan kerjasama kemitraan. Hasil penelitian menunjukkan bahwa sebagian besar petani plasma teh berminat untuk melanjutkan kerjasama kemitraan. Faktor usia petani, produksi teh, dan efektivitas kemitraan memiliki pengaruh signifikan terhadap kesediaan petani untuk melanjutkan kerjasama kemitraan intiplasma.
\end{abstract}

Kata Kunci: kemitraan, pagilaran, petani, teh

\section{PENDAHULUAN}

Kerjasama kemitraan perkebunan telah berlangsung kurang lebih 4 dekade yang lalu atau sejak 1970an sejak diterbitkannya Keputusan Presiden Indonesia Nomor 11
Tahun 1974, yang pada intinya mendorong perusahaan perkebunan negara (BUMN) untuk berperan sebagai Pembina perkebunanperkebunan rakyat di sekitarnya, atau istilahnya bertindak sebagai perkebunan inti. Pola kemitraan inti-plasma terus mengalami 
Perwitasari, H., Widada, A. W., Pranyoto, A., Mulyo, J. H., Sugiyarto, Anggrasari, H.: Keberlanjutan Kemitraan Petani Plasma Teh ...

dinamika dan perubahan dalam rangka menjamin keberlanjutan dengan mengakomodasi kepentingan kedua pihak, yaitu perusahaan inti untuk memperoleh profit dan mengembangkan bisnisnya, dan petani untuk memperbaiki tingkat kesejahteraannya.

Saputra et al. (2017) menyatakan bahwa kerjasama kemitraan umumnya disepakati secara tertulis dengan klausul kewajiban dan hak yang jelas antara kedua pihak, inti dan plasma. Namun demikian, pada praktiknya sering kali ada ketidakharmonisan dalam kerjasama karena ketidakpuasan kinerja satu pihak pada kinerja pihak lain. Plasma terkadang tidak puas dengan pola kerja yang dilakukan inti, di antaranya permasalahan sertifikasi, harga beli dan banyak biaya-biaya yang tidak terduga. Disisi lain, plasma juga secara relatif tidak konsisten dalam memasok produk. Masuknya perusahaan lain (tengkulak) di antara inti dan plasma menambah pola kemitraan menjadi terlihat kurang efektif (Saleh, 2015). Struktur pola kemitraan menjadi penting dalam melaksanakan program inti plasma pada perkebunan. Hal tersebut berguna untuk menanggulangi hambatan struktural pada pasar global dan mengurangi kesenjangan pada pasar lokal. Sejalan dengan Saputra et al. (2017), komitmen kedua belah pihak yaitu inti dan plasma merupakan kunci utama dalam pola kemitraan. Beragamnya latar belakang plasma dapat dikaburkan dengan menjadikannya kelompok kemitraan yang lebih komunikatif dan terbuka. Komunikasi yang menyeluruh dengan pengembangan modal sosial dapat mendukung atmosfer kemitraan yang lebih tangguh. Kemitraan merupakan solusi yang tepat untuk percepatan kemajuan pembangunan (Kurniaty et al., 2018)

Efektivitas juga menjadi sorotan guna kesinambungan kemitraan inti dan plasma. Kesepakatan dalam bentuk perjanjian (sebagai contoh diwakili oleh koperasi), pelaporan hasil produksi, pelaporan hasil penjualan, pembinaan oleh inti kepada plasma dapat dijadikan instrumen atau ukuran sederhana untuk mengetahui efektivitas kemitraan. Tingkat kepuasan secara kualitatif dapat mengukur hal tersebut. Namun, Ala et al. (2015) menyelidiki bahwa efektivitas kemitraan belum bisa dikatakan memiliki pengaruh yang signifikan dengan kepuasan dan lebih jauh lagi dengan peningkatan pendapatan plasma.

Kemitraan perkebunan dengan pola kerjasama inti plasma tidak hanya ada di Luar Jawa saja yang terkenal banyak lahan perkebunannya. Kerjasama kemitraan, walaupun skalanya terbatas, juga terdapat di Pulau Jawa, salah satunya kerjasama kemitraan inti plasma yang dijalankan oleh PT. Pagilaran dan para petani plasma teh di sekitarnya.

Dinamika yang terjadi pada pola kemitraan inti plasma tidak dapat dihindari, yaitu pasang-surutnya kinerja kemitraan yang berlangsung, tetapi hal ini harus dipandang sebagai bagian penting untuk mengevaluasi kemitraan sehingga ke depan kerjasama kemitraan akan dapat memberikan manfaat yang seadil-adilnya bagi kedua belah pihak. Tulisan ini berusaha untuk melihat bagaimana peluang keberlanjutan kemitraan dari sudut pandang petani sebagai mitra plasma, dan mengkaji faktor-faktor apa saja yang berpengaruh nyata pada kesediaan untuk melanjutkan kemitraan tersebut.

\section{METODE PENELITIAN}

Lokasi penelitian dipilih secara purposif yakni di Desa Kaliboja dan Desa Kaliombo, Kecamatan Paninggaran, Kabupaten Pekalongan. Dua desa tersebut dipilih karena merupakan desa dengan populasi petani plasma teh terbanyak yang bermitra dengan PT. Pagilaran dengan pola kemitraan inti-plasma. Jumlah sampel dalam penelitian ini adalah 90 petani yang dipilih dengan metode convenience sampling.

Kesediaan petani dalam melanjutkan kerjasama kemitraan dengan PT. Pagilaran, dianalisis secara deskriptif yang mengukur tingkat kesediaan petani dalam melanjutkan kerjasama kemitraan. Tingkat kesediaan melanjutkan ini diukur dengan skala Likert yang mengambil rentang 1-5, dengan deskripsi " 1 = sangat tidak bersedia, 2 = tidak bersedia, 3 = ragu-ragu, $4=$ bersedia, dan $5=$ sangat bersedia".

Faktor-faktor yang diduga memengaruhi kesediaan petani dalam melanjutkan kerjasama kemitraan diuji dengan menggunakan analisis regresi ordinal logit. Beberapa faktor diduga 
Perwitasari, H., Widada, A. W., Pranyoto, A., Mulyo, J. H., Sugiyarto, Anggrasari, H.: Keberlanjutan Kemitraan Petani Plasma Teh ...

$\operatorname{Pr}\left(Y=4 \mid X_{1}, X_{2}, \ldots, X_{6}, D_{J K}\right)=\frac{1}{1+e^{-\left(\beta_{0}+\beta_{1} X_{1}+\ldots+\beta_{6} X_{6}+\delta D_{J K}\right)}}$

dimana:

$Y=$ tingkat kesediaan petani untuk melanjutkan kemitraan (" $1=$ sangat tidak bersedia, $2=$ tidak bersedia, 3 = ragu-ragu, 4 = bersedia, dan $5=$ sangat bersedia")

$X_{1} \quad=$ Usia petani (th)

$X_{2}=$ Luas lahan $\left(\mathrm{m}^{2}\right)$

$X_{3}=$ Produksi teh $(\mathrm{kg})$

$X_{4} \quad=$ Pendampingan

$X_{5}=$ Partisipasi

$X_{6}=$ Efektivitas

$D_{J K}=$ Jenis Kelamin $(\mathrm{D}=1$, bila laki-laki $)$

berpengaruh terhadap keberlanjutan kemitraan di antaranya luas lahan teh, produksi teh, pendampingan, partisipasi petani, efektivitas, serta faktor petani meliputi usia dan jenis kelamin. Adapun model regresi seperti dalam persamaan (1).

Selanjutnya dilakukan interpretasi atas output regresi meliputi:

\section{Nagelkerke Pseudo R-square}

Pseudo $\mathrm{R}^{2}$ ditujukan untuk mengukur kekuatan hubungan (strengh of association) antara variabel independen dan dependen. Nilainya berkisar dari 0 hingga 1 , dimana 0 mengindikasikan bahwa variabel independen tidak dapat digunakan untuk memprediksi variabel dependen (Gujarati, 2003).

\section{Uji Likelihood Ratio (LR)}

Uji $L R$ digunakan untuk mengetahui tingkat pengaruh semua variabel independen secara bersama-sama terhadap variabel dependen. Dalam hal ini formulasi $L R$ menurut (Greene, 2012) sebagai berikut:

$L R=\frac{n^{\prime}\left(R^{2}\right)}{2\left(1-R^{2}\right)}$

Keterangan :

$n^{\prime}=$ jumlah sampel dikurangi jumlah
$R^{2}=$ variabel bebas

Adapun formula hipotesisnya adalah sebagai berikut :
Ho : $\quad \beta 1=\beta 2=\ldots .=\beta i=0$, artinya tidak ada pengaruh variabel independen terhadap variabel dependen.

$H a$ : salah satu $\beta i \neq 0$, artinya ada pengaruh variabel independen terhadap variabel dependen.

$L R$ dibandingkan dengan Chi Square tabel $\left(X^{2}\right)$. Jika $L R$ hitung > Chi Square tabel berarti $H o$ ditolak. Hal ini menunjukkan bahwa variabel independen secara bersama-sama berpengaruh nyata terhadap variabel dependen.

\section{Wald Test (Z)}

Uji ini digunakan untuk menguji pengaruh masing-masing variabel independen terhadap variabel dependen melalui perubahan odds.

Adapun formula hipotesisnya (Greene, 2012) adalah sebagai berikut :

Ho: $\quad \beta i=0$ atau Ho: ORi (odd ratio $)=1$, artinya tidak ada pengaruh variabel independen ke- $i$ terhadap variabel dependen (kesediaan melanjutkan kerjasama kemitraan)

$H a: \quad \beta \mathrm{i} \neq 0$, artinya ada pengaruh variabel independen ke- $i$ terhadap variabel dependen (kesediaan melanjutkan kerjasama kemitraan)

$W$ hitung $($ Wald $)=\left(\frac{\beta}{S E}\right)^{2}=\mathrm{z}$

$W$ hitung dibandingkan dengan Chi Square tabel $\left(X^{2}\right)$. Jika $W$ hitung $>$ Chi Square tabel $\left(X^{2}\right)$ berarti Ho ditolak atau variabel independen yang diuji secara individu berpengaruh nyata terhadap variabel dependen. 
Perwitasari, H., Widada, A. W., Pranyoto, A., Mulyo, J. H., Sugiyarto, Anggrasari, H.: Keberlanjutan Kemitraan Petani Plasma Teh ...

\section{HASIL DAN PEMBAHASAN}

\section{Kesediaan Petani untuk Melanjutkan Kerjasama Kemitraan Inti Plasma}

Kesediaan untuk melanjutkan kemitraan antara petani teh dengan PT Pagilaran menjadi hal yang penting bagi kedua belah pihak. Dengan petani yang memiliki kesediaan untuk melanjutkan kemitraan, maka akan mendukung sekuritas dari PT Pagilaran dalam menyuplai input. Hal tersebut akan berdampak pada optimalisasi kapasitas produksi dan keuntungan yang diperoleh. Dengan demikian, akan manfaat akan kembali kepada petani teh sebagai mitra yang juga dapat terjamin keberlanjutan usaha taninya karena memiliki pangsa pasar yang jelas. Berdasarkan hasil penelitian dapat diketahui bahwa petani yang sangat bersedia untuk melanjutkan kemitraan sebesar 28 persen, bersedia melanjutkan kemitraan sebesar 6 persen, petani yang raguragu untuk melanjutkan kemitraan tidak ada, petani yang tidak bersedia melanjutkan hanya 8 persen serta petani yang sangat tidak bersedia melanjutkan kemitraan bahkan hanya 1 persen. Secara keseluruhan, rata-rata petani masih bersedia untuk melanjutkan kemitraan dengan PT Pagilaran.

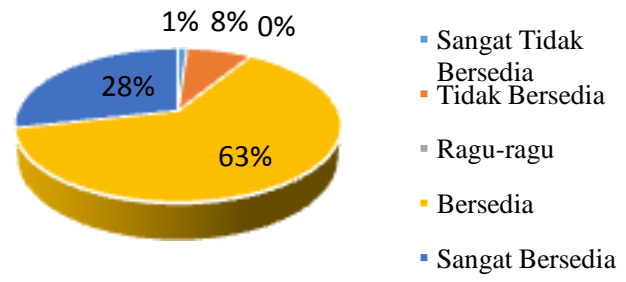

Gambar 1. Kesediaan petani untuk melanjutkan kemitraan inti-plasma dengan PT. Pagilaran Sumber: Analisis data primer (2019)

Kinerja kemitraan, pendampingan PT Pagilaran, partisipasi petani dalam kemitraan dan efektivitas kemitraan dapat mendorong petani untuk dapat melanjutkan kemitraan antara petani dengan PT Pagilaran. Deskripsi dari faktor-faktor tersebut yaitu:

\section{Kinerja Kemitraan}

Di sektor pertanian, banyak perusahaan bekerja sama dengan petani berdasarkan kontrak (Trebbin, 2014). Perusahaan biasanya tidak dapat membeli tanah pedesaan, tetapi memiliki modal, pengetahuan produksi dan pemasaran, sebaliknya, petani memiliki hak untuk menggunakan tanah, tetapi mereka umumnya kurang berpendidikan, produksi tidak efisien dan infrastruktur terbelakang (Wang et al., 2014). Adanya pola kemitraan antara petani dengan PT. Pagilaran dapat meningkatkan kinerja pelaku agribisnis khususnya petani atau pengusaha kecil. Pada pola kemitraan tersebut, perusahaan memberikan fasilitas kepada petani dan perusahaan menerima pasokan dari petani sehingga kerjasama antara kedua belah pihak dapat saling menguntungkan dan bertanggungjawab (Fidyansari et al., 2016; Jia dan Bijman, 2014). Perusahaan dan petani memperoleh manfaat win-win daripada model menang kalah (Fu et al., 2017) sehingga kemitraan tersebut lebih memberikan manfaat bagi kedua belah pihak.

Kinerja kemitraan antara petani teh dengan PT Pagilaran memiliki rata-rata capaian 73,21 persen. Kinerja kemitraan tersebut dibentuk dari 16 item pernyataan yaitu (1) Prosedur bermitra dengan PT Pagilaran jelas, (2) Syarat kemitraan dengan pihak PT Pagilaran mudah dimengerti, (3) Syarat kemitraan dengan pihak PT Pagilaran jelas, (4) Syarat kemitraan dengan pihak PT Pagilaran mudah dimengerti, (5) Syarat bermitra dengan pihak PT Pagilaran tidak merepotkan petani teh mitra, (6) Kemitraan usaha dengan PT Pagilaran memiliki tujuan yang jelas, (7) PT Pagilaran memberikan pelatihan bagi petani teh mitra, (8) Pelatihan yang dilakukan memberikan manfaat bagi para petani teh mitra, (9) PT Pagilaran memberikan pembinaan bagi para petani teh mitra, (10) Pembinaan yang diberikan PT Pagilaran dapat memberikan solusi bagi petani teh mitra, (11) PT Pagilaran melakukan monitoring kepada petani teh mitra, Pihak PT Pagilaran menguasai materi yang diberikan baik dalam pelatihan, dan (12) Pihak PT Pagilaran memberikan pelayanan yang ramah kepada petani teh mitra. Hampir semua item pernyataan tersebut memiliki rata-rata capaian tinggi, hanya item ke-13 yang memiliki capaian sedang.

\section{Pendampingan PT Pagilaran}

Petani yang menjalani kemitraan dengan suatu lembaga atau perusahaan, biasanya mendapatkan bantuan modal berupa bibit, pupuk dan pestisida dalam bentuk paket kredit dan bantuan teknologi kepada petani, dan 
Perwitasari, H., Widada, A. W., Pranyoto, A., Mulyo, J. H., Sugiyarto, Anggrasari, H.: Keberlanjutan Kemitraan Petani Plasma Teh ...

petani sebagai mitra perusahaan juga diwajibkan untuk menjual hasil pertaniannya kepada pihak perusahaan sesuai dengan ketentuan dalam surat perjanjian bentuk hubungan kerjasama dalam menjalankan kemitraan (Erfit, 2011). Selain itu petani sebagai mitra juga mendapatkan pendampingan manajemen produksi (Sita et al., 2018)

Pembinaan yang dilakukan oleh PT Pagilaran kepada petani berupa pinjaman dalam uang untuk membeli bibit teh, bibit teh yang diberikan sehat dan berkualitas, memberikan jangka waktu pengembalian untuk pinjaman, syarat meminta bantuan bibit teh mudah untuk dipenuhi, prosedur meminta bantuan bibit teh mudah untuk dipenuhi, pupuk untuk petani teh, kualitas pupuk yang diberikan pada petani teh mitra lebih baik dibandingkan kualitas pupuk yang dijual di luar, harga pupuk yang disediakan PT Pagilaran lebih murah daripada yang dijual di luar, pelatihan pemeliharaan tanaman (pemupukan) yang sesuai Good Agricultural Practices (GAP), pembinaan tentang kualitas pucuk teh yang baik, pengarahan dalam pencatatan usaha tani teh, laporan kepada pihak PT Pagilaran mengenai kondisi kebun, standar harga yang pas bagi petani teh, serta keterbukaan informasi harga beli pucuk teh pada petani teh mitra. Pendampingan tersebut mempunyai capaian rata-rata yang sedang. Namun, pinjaman uang untuk pembelian bibit, jangka waktu pinjaman, syarat dan prosedur permintaan bantuan bibit, penyediaan pupuk, serta harga pupuk masih masuk pada rata-rata capaian yang rendah. Sebaliknya, pelatihan GAP, pembinaan kualitas pucuk dan jaminan pasar dengan melalui $\mathrm{MoU}$ masuk pada rata-rata capaian yang tinggi. Menurut Hamidi (2010), pendampingan yang diberikan oleh mitra perusahaan kepada petani dapat memberikan keuntungan. Selain itu, tingkat produktivitas, harga output, harga input berpengaruh signifikan terhadap keuntungan sebagai dampak dari kemitraan.

\section{Partisipasi Petani dalam Kemitraan}

Partisipasi merupakan keikutsertaan dari seseorang atau sekelompok orang untuk meningkatkan potensi terhadap suatu organisasi (Wildayana et al., 2011). Bagi petani, keterlibatan dalam kemitraan dapat mengurangi risiko ketidakpastian dalam pemasaran produk
(Hamidi, 2014), dan juga dapat memotong rantai pemasaran (Charatsari et al., 2018)

Partisipasi petani dalam kemitraan dengan PT Pagilaran dapat dilihat dari pemeliharaan kebun teh yang sesuai dengan standar yang ditetapkan oleh PT Pagilaran, seluruh tanaman teh yang dimiliki yaitu tanaman produktif, meminjam atau penerima bantuan bibit teh dari PT Pagilaran, kondisi kebun teh sesuai standar yang ditetapkan PT Pagilaran, menjaga kesehatan tanaman dan kebun teh yang miliki, mengaplikasikan pupuk sesuai dosis, menggunakan pupuk yang disediakan oleh PT Pagilaran, mengikuti program pelatihan penanganan penyakit yang diberikan PT Pagilaran, menjual pucuk teh ke pedagang selain PT Pagilaran, kualitas pucuk teh yang dijual ke PT Pagilaran pucuk dengan kualitas terbaik, harga yang ditawarkan selain PT Pagilaran kadang lebih baik, dan merasa puas dengan harga per kilogram pucuk teh yang diberikan PT Pagilaran. Rata-rata capaian partisipasi kemitraan masuk pada kategori tinggi kecuali peminjaman bibit serta penjualan pucuk teh ke luar PT Pagilaran (memiliki ratarata capaian yang rendah). Hal ini disebabkan masih adanya beberapa petani mitra yang kedapatan melakukan penjualan hasil produksi teh kepada pihak luar saat ada perbedaan harga yang ditawarkan.

\section{Efektivitas Kemitraan}

Pendampingan yang dilakukan oleh PT Pagilaran masih dalam kategori rata-rata capaian yang tinggi. Pendampingan PT Pagilaran terdiri dari 17 item pernyataan antara lain: (1) Terjadi peningkatan pendapatan setelah bermitra dengan PT Pagilaran, (2) Kualitas produksi teh meningkat setelah bermitra dengan PT Pagilaran, (3) Jumlah produksi teh meningkat setelah bermitra dengan PT Pagilaran, (4) Tidak perlu mencari pembeli untuk membeli semua hasil produksi teh, (5) Produksi teh dibeli oleh PT Pagilaran di atas harga standar, (6) Pelatihan yang diberikan PT Pagilaran memberikan banyak perubahan pada usaha tani teh, (7) Pembinaan yang diberikan PT Pagilaran memberikan banyak perubahan pada usaha tani teh, (8) Kemitraan dengan PT Pagilaran memberikan banyak keuntungan, serta (9) Terjadi penurunan biaya usaha tani teh setelah bermitra dengan PT Pagilaran. Rata-rata capaian dari item 
Perwitasari, H., Widada, A. W., Pranyoto, A., Mulyo, J. H., Sugiyarto, Anggrasari, H.: Keberlanjutan Kemitraan Petani Plasma Teh ...

pernyataan ke-3, 5, 6 dan 9 masih masuk pada kategori sedang sedangkan sisanya masuk pada kategori tinggi. Menurut Kurniaty et. al. (2018), membangun kemitraan antara perusahaan dengan petani teh sangat penting untuk memberikan peluang jalan masuk menuju kemandirian petani terutama dalam memasarkan hasil produksinya atau bermitra dalam program meningkatkan hasil produksinya.

Tabel 1. Faktor kesediaan untuk melanjutkan kemitraan dengan PT Pagilaran

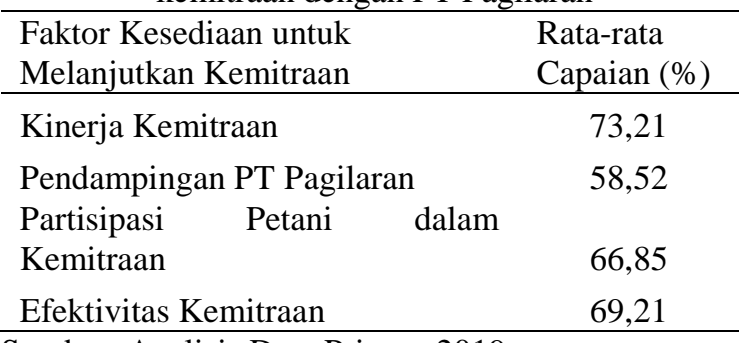

Sumber: Analisis Data Primer, 2019.

\section{Faktor-faktor yang Memengaruhi Keberlanjutan Kemitraan Inti-Plasma}

Faktor-faktor yang diduga berpengaruh nyata terhadap tingkat kesediaan petani plasma teh untuk melanjutkan kerjasama kemitraan dianalisis dengan regresi. Model regresi tersebut yaitu faktor-faktor yang diduga berpengaruh tersebut sebagai variabel independen terhadap tingkat kesediaan petani sebagai variabel dependen.

Berdasarkan hasil analisis kesesuaian model, diketahui bahwa penambahan variabel independen memberikan pengaruh yang berbeda terhadap model bila dibandingkan dengan hanya ada intersep saja (nilai sig. 0.00). Hal ini menginformasikan bahwa model dengan prediktor memberikan hasil yang lebih baik dalam menduga variabel dependen. Goodness of Fit juga sering disebut dengan uji kecocokan model. Dari uji kecocokan model ini, didapatkan hasil bahwa nilai Chi-Square untuk Pearson dan Deviance keduanya memiliki nilai p-value lebih dari 0.05 . Hal ini menunjukkan bahwa model yang digunakan dalam analisis regresi ini cocok dan dapat digunakan dalam analisis lebih lanjut. Pseudo $R$-Square merupakan uji yang dilakukan untuk mengetahui kualitas model dari sisi kemampuan variabel independen dalam menjelaskan kesediaan untuk melanjutkan kemitraan sebagai variabel dependennya.
Dalam OLS, Pseudo R-Square kurang lebih dapat disejajarkan dengan koefisien determinasi. Koefisien determinasi yang digunakan adalah nilai dari Nagelkerke yaitu sebesar 0.605. Nilai ini menunjukkan bahwa variasi variabel independen di dalam model mampu menjelaskan variabel dependennya sebesar $60.5 \%$, sedangkan sisanya dijelaskan oleh variabel lain di luar model. Nilai koefisien determinasi ini tergolong cukup besar dan dinilai baik bahwa sebagian besar variabel di dalam model mampu untuk menjelaskan kesediaan melanjutkan kemitraan.

Hasil regresi menunjukkan bahwa dari daftar variabel independen yang diduga memengaruhi kesediaan petani untuk melanjutkan kemitraan dalam berusaha tani teh dengan PT. Pagilaran terdapat variabel yang berpengaruh signifikan secara statistik. Beberapa variabel independen yang berpengaruh secara signifikan pada taraf $\alpha=$ $10 \%$ yaitu usia dan produksi teh, sedangkan variabel independen yang berpengaruh secara signifikan terhadap kelanjutan kemitraan teh pada taraf $\alpha=1 \%$ yaitu efektivitas.

Usia berpengaruh signifikan tetapi memberikan efek yang negatif. Saat ini petani teh yang bermitra dengan PT. Pagilaran didominasi oleh petani dengan rentang usia yang tergolong produktif. Pertambahan usia akan memberikan pengaruh pada berkurangnya kesediaan petani untuk melanjutkan kemitraan. Hal ini disebabkan seiring petani tersebut tua (melewati masa produktif), maka kemampuan fisik petani dalam mengusahakan tanaman teh yang sebagian besar ditanam di areal dataran tinggi dan dengan kemiringan tinggi akan berkurang. Usia petani akan memengaruhi kemampuan fisik dalam bekerja dan cara berpikir. Usia petani yang lebih muda biasanya cenderung lebih agresif dan lebih dinamis dalam berusaha jika dibandingkan dengan umur yang lebih tua sehingga usia juga dapat berpengaruh terhadap kinerja dalam mengelola usaha taninya (Lesmana dan Ratina, 2011). Seiring bertambahnya usia, petani mulai cenderung mencari sumber penghidupan yang lebih mudah dan mampu dijangkau sesuai dengan kemampuan fisik. Sebagian petani yang lain menyampaikan bahwa mereka akan mulai tidak lagi bermitra karena lahan tersebut nantinya akan diwariskan dan kemitraan akan dilanjutkan oleh keturunannya. 
Perwitasari, H., Widada, A. W., Pranyoto, A., Mulyo, J. H., Sugiyarto, Anggrasari, H.: Keberlanjutan Kemitraan Petani Plasma Teh ...

Tabel 2. Faktor-faktor yang memengaruhi kesediaan petani untuk melanjutkan kemitraan inti-plasma

\begin{tabular}{|c|c|c|c|c|}
\hline & $\begin{array}{l}\text { Koefisien } \\
\text { (std error) }\end{array}$ & Wald & Sig. & $($ Exp. $\beta)$ \\
\hline \multicolumn{5}{|l|}{ Threshold } \\
\hline $\mathrm{Y}=1$ & $\begin{array}{r}0,919 \\
(2,164)\end{array}$ & 2,164 & 0,671 & 2,507 \\
\hline $\mathrm{Y}=2$ & $\begin{array}{r}4,396 \\
(2,020) \\
\end{array}$ & 2,020 & $0,030^{* *}$ & 81,158 \\
\hline $\mathrm{Y}=5$ & $\begin{array}{l}11,036 \\
(2,726)\end{array}$ & 2,726 & $0,000 * * *$ & 62070 \\
\hline $\mathrm{X}_{1}$ (Usia) & $\begin{array}{r}-0,039 \\
(0,023) \\
\end{array}$ & 2,892 & $0,089^{*}$ & 0,962 \\
\hline X2 (Luas lahan) & $\begin{array}{r}-7,588 \mathrm{E}-05 \\
(0,000) \\
\end{array}$ & 0,786 & 0,375 & 0,999 \\
\hline X3 (Produksi teh) & $\begin{array}{r}0,000 \\
(0,000) \\
\end{array}$ & 2,747 & $0,097 *$ & 1,000 \\
\hline X4 (Pendampingan) & $\begin{array}{r}-3,394 \\
(2,673)\end{array}$ & 1,612 & 0,204 & 0,034 \\
\hline X5 (Partisipasi) & $\begin{array}{r}1,285 \\
(2,105)\end{array}$ & 0,373 & 0,542 & 3,615 \\
\hline X6 (Efektivitas) & $\begin{array}{r}17,689 \\
(4,166)\end{array}$ & 18,030 & $0,000 * * *$ & 48.087.374 \\
\hline DJK $($ Jenis kelamin=1) & $\begin{array}{r}-0,753 \\
(, 561)\end{array}$ & 1,799 & 0,180 & 0,471 \\
\hline
\end{tabular}

Sumber: Analisis Data Primer, 2019.

Keterangan:

* $\quad$ : signifikan pada $\alpha=10 \%$

** $\quad$ : signifikan pada $\alpha=5 \%$

*** $\quad$ signifikan pada $\alpha=1 \%$

Produksi teh berpengaruh secara signifikan dengan tanda positif. Hal ini menunjukkan bahwa semakin banyaknya produksi teh yang dihasilkan, maka petani teh akan mempunyai kecondongan untuk bersedia menguatkan kemitraan dengan PT. Pagilaran. Hal ini didasari bahwa PT. Pagilaran merupakan unit pengolahan teh dengan kapasitas produksi yang cukup besar sehingga mempunyai kemampuan menyerap hasil panen dari petani mitra dengan sangat baik. Petani dengan produksi teh yang meningkat cenderung akan menguatkan kemitraan karena petani membutuhkan jaminan penyerapan hasil panen sehingga panen teh yang semakin banyak tersebut dapat terjual. Selain mengamankan pasar, petani yang berpartisipasi dalam kemitraan diberikan kredit untuk input produksi seperti benih, pupuk dan pestisida oleh perusahaan mitra (Hamidi, 2010).

Efektivitas dalam proses kemitraan antara petani teh dengan PT. Pagilaran mempunyai pengaruh yang sangat besar dalam menjamin keberlanjutan kemitraan teh di masa yang akan datang. Efektivitas kemitraan ditentukan oleh indikator semakin meningkatnya pendapatan petani setelah bermitra dengan PT. Pagilaran. Peningkatan pendapatan ini dapat dilakukan dengan upaya peningkatan produksi teh dengan usaha tani terpadu serta pemberian harga beli yang kompetitif. Peningkatan pendapatan petani dari proses jual beli memengaruhi petani untuk terus bermitra dengan perusahaan tersebut sehingga adanya kemitraan dapat meningkatkan pendapatan petani (Fischer et al., 2012; Naim et al., 2015; Wibowo, 2013). Beberapa studi empiris lainnya juga menunjukkan dampak kemitraan dalam pertanian, kemitraan ini dapat meningkatkan produksi dan pendapatan petani sebagai akibat dari penggunaan teknologi baru, pengurangan biaya transportasi dan biaya pemasaran (Hamidi, 2014). Efektivitas juga ditentukan oleh meningkatnya kualitas teh yang disetorkan pada PT. Pagilaran. Usaha tani terpadu dengan SOP yang ditetapkan oleh PT. Pagilaran diharapkan dapat meningkatkan kualitas dan kuantitas teh petani, meningkatkan efisiensi 
Perwitasari, H., Widada, A. W., Pranyoto, A., Mulyo, J. H., Sugiyarto, Anggrasari, H.: Keberlanjutan Kemitraan Petani Plasma Teh ...

dan penurunan biaya produksi sehingga petani bisa mendapat keuntungan lebih besar.

Luas lahan petani rata-rata pada kategori sedang yaitu $2.000-10.000 \mathrm{~m}^{2}$ dengan distribusi 64\%. Selain itu, pendampingan PT Pagilaran mempunyai capaian rata-rata yang sedang sebesar 56 persen bahkan rata-rata capaian partisipasi kemitraan masuk pada kategori tinggi terutama terkait aspek bagi hasil yaitu $100 \%$. Dengan demikian, karakteristik luas lahan, pendampingan dan partisipasi relatif homogen sehingga dapat menyebabkan tidak memengaruhi kesediaan petani untuk melanjutkan kemitraan inti plasma.

\section{KESIMPULAN}

Mayoritas petani plasma teh mau untuk melanjutkan kemitraan inti-plasma dengan PT. Pagilaran. Usia memberikan efek yang negatif terhadap kesediaan untuk melanjutkan kerjasama kemitraan sedangkan produksi dan efektivitas kemitraan memberikan efek yang positif terhadap kesediaan untuk melanjutkan kerjasama kemitraan. Keberlanjutan kemitraan yang semakin baik ke depannya dapat ditempuh dengan menjalin kerja sama bersama petani muda, selain itu diperlukan adanya penjaminan kualitas sarana produksi seperti bibit unggul, pupuk, dan kemudahan pembiayaan, serta pola kemitraan yang lebih berada pada sisi kebutuhan petani mitra.

\section{DAFTAR PUSTAKA}

Ala, K., Juraemi, \& Suhadi, I. (2015). Efektivitas kemitraan inti plasma perkebunan kelapa sawit (studi kasus pada petani plasma PT. Gunta Samba Kecamatan Kongbeng). Jurnal Pertanian Terpadu, 3(1), 76-88.

Charatsari, C., Kitsios, F., Stafyla, A., Aidonis, D., \& Lioutas, E. (2018). Antecedents of farmers ' willingness to participate in short food supply chains. British Food Journal, 120(10), 2317-2333. https://doi.org/10.1108/BFJ-09-20170537.

Erfit. (2011). Analisis komparatif kemitraan contract farming dan nonocontract farming pada agribisnis hortikultura.
Jurnal Paradigma Ekonomika, 1(3), 114.

Fidyansari, D., Hastuty, S., \& Arianto, I. K. (2016). Faktor-faktor yang memengaruhi petani kakao bermitra dengan PT Mars (studi kasus di Desa Cendana Hijau Kecamatan Wotu Kabupaten Luwu Timur). Jurnal Perbal, 4(2), 1-13.

Fischer, E., Qaim, M., \& Goettingen, G. (2012). Linking smallholders to markets : determinants and impacts of farmer collective action in Kenya. World Development, 40(6), 1255-1268. https://doi.org/10.1016/j.worlddev.2011. 11.018 .

Fu, S., Han, Z., \& Huo, B. (2017). Relational enablers of information sharing: Evidence from Chinese food supply chains. Journal of Industrial Management \& Data Systems, 117(5), 838-852. https://doi.org/10.1108/IMDS04-2016-0144.

Greene, W. H. (2012). Econometric Analysis (Seventh Ed). Pearson.

Gujarati, D. N. (2003). Basic Econometric Fourth Edition.

Hamidi, H. (2010). The impact of contract farming on the profit of virginia tobacco farming in Lombok Islind, West Nusa Tenggara. Journal of Indonesian Economy and Business, 25(1), 29-40.

Hamidi, H. (2014). The impact on farm profits of a company's partnership with a potato farm. Journal of Indonesia Economy and Business, 29(2), 118-128.

Jia, X., \& Bijman, J. (2014). Contract Farming: Synthetic themes for linking farmers to demanding markets (C. A. da Silva \& M. Ranking (eds.); Contract F). FAO.

Kurniaty, T., Trismiaty, \& Martini, R. (2018). Pola kemitraan usahatani teh di Kabupaten Kulonprogo. Jurnal Masepi, $3(1), 1-9$.

Lesmana, D., \& Ratina, R. (2011). Hubungan presepsi dan faktor-faktor sosial ekonomi 
Perwitasari, H., Widada, A. W., Pranyoto, A., Mulyo, J. H., Sugiyarto, Anggrasari, H.: Keberlanjutan Kemitraan Petani Plasma Teh ...

terhadap keputusan petani mengembangkan pola kemitraan petani plasma mandiri kelaoa sawit (Elaeis guineensis Jacq.) di Kelurahan Bantuas Kecamatan Palaran Kota Samarinda. $E P P, 8(2), 8-17$.

Naim, S., Sasongko, L. A., \& Nurjayanti, E. D. (2015). Pengaruh kemitraan terhadap pendapatan usahatani Tebu. Mediagro, 11(1), 47-59.

Saleh, M. (2015). Studi tentang pola kemitraan PT. Perkebunan Nusantara XII dalam meningkatkan perekonomian masyarakat di Desa Semuntai Kecamatan Long Ikis Kabupaten Paser. EJournal Ilmu Pemerintahan, 3(4), 1527-1538.

Saputra, I. M. G. D., Anggreni, I. G. A. A. L., \& Dharma, I. P. (2017). Pola kemitraan usaha tani kelapa sawit kelompok tani Telaga Biru dengan PT. Sawindo Kencana melalui koperasi di Kabupaten Bangka Barat Provinsi Bangka Belitung. E-Jurnal Agribisnis Dan Agrowisata, 6(2), 249-258.

Sita, K., Aji, T. M., \& Rosyadi, A. I. (2018). Contract farming through tea horticulture intercropping system : a case study of Gambung Estate and horticultural farmers in Bandung , Indonesia. Asian Journal of Agriculture and Departement, 15(1), 75-85.

Trebbin, A. (2014). Linking small farmers to modern retail through producer organizations- Experiences with producer companies in India. Journal of Food Policy, 45, 35-44. https://doi.org/10.1016/j.foodpol.2013.12 .007

Wang, H. H., Wang, Y., \& Delgado, M. S. (2014). The transition modern agriculture: Contract Farming in Developing Economies. Amer. J. Agr. Econ, 96(5), 1257-1271. https://doi.org/10.1093/ajae/aau036

Wibowo, E. (2013). Pola kemitraan antara petani Tebu Rakyat Kredit (TRK) dan Mandiri (TRM) dengan pabrik gula modjopanggoong Tulungagung. Jurnal Manajemen Agribisnis, 13(1), 1-12.

Wildayana, E., Zahri, I., Mulyana, A., \& Husin, L. (2011). Partisipasi petani plasma pola kemitraan pir-trans kelapa sawit di Sumatera Selatan. Prosiding Seminar Nasional Perhepi, Kemitraan, 978-979. 